\title{
WYŁĄCZENIE CZŁONKA ORGANU KOLEGIALNEGO W OGÓLNYM POSTĘPOWANIU ADMINISTRACYJNYM
}

I. Jednym z podstawowych obowiązków organu administracji publicznej $\mathrm{w}$ postępowaniu administracyjnym jest jego prowadzenie w sposób budzący zaufanie uczestników postępowania do władzy publicznej. Wynika on wprost z ogólnej zasady zaufania, uznawanej za najszersza pod względem zakresu, za „klamrę, która spina całość zasad postępowania”' Przepis art. 8 § 1 k.p.a., który stanowi dla tej zasady oparcie prawne, podkreśla tym samym fundamentalna wartość, jaką w systemie prawnym jest zaufanie, i nakazuje jej realizowanie $^{2}$. Jest to nie tylko wartość procesowa ze skutkami odnoszacymi się do granic postępowania. Osiagnięte zaufanie przekracza ramy procesowe i bezpośrednio wpływa na ocenę funkcjonowania administracji publicznej, nieraz także w szerszym wymiarze podmiotowym. Trzeba jednak zauważyć, że wskazana zasada ogólna nie akcentuje (nie wymaga) osiagnięcia skutku w postaci zbudowania tego zaufania czy też w przypadku już istniejącego zaufania - jego pogłębienia, a tylko działania „w sposób budzący zaufanie”.

Formuła art. 8 § 1 k.p.a. podkreśla, że jest to zasada skierowana do „postępowania”. Odnosi się zatem do wszystkich jego postaci i stadiów. Sam „sposób” prowadzenia postępowania, który spełniałby wymóg budzącego zaufanie, nie został w przepisie dookreślony ani co do koniecznej techniki procesowej, ani co do innych elementów statyki lub dynamiki postępowania. Nie oznacza to jednak, że Kodeks pozostawia ten „sposób” bez jakiegokolwiek zainteresowania, a tym samym oddziaływania. Znowelizowany przepis art. $8 \S 1$ in fine wskazuje trzy dalsze zasady, którymi kierowanie się jest obowiązkiem organu, a które spełniaja funkcję zasad (kryteriów) szczegółowych w stosunku do ogólnej zasady zaufania. Sa nimi zasady: proporcjonalności, bezstronności i równego traktowania. Wpływają one, choć z różnym nasileniem, na sposób prowadzenia postępowania.

II. Wymóg zapewnienia bezstronności postępowania nie jest nowym obowiązkiem organu administracji publicznej. Nowością jest jego wyodrębnienie $\mathrm{w}$ art. $8 \S 1$ k.p.a., a tym samym podkreślenie rangi. Już poprzednie brzmienie art. 8 k.p.a. (zasada pogłębiania zaufania obywateli do organów Państwa) stanowiło podstawę do formułowania wymogu bezstronności ${ }^{3}$. Wskazywano,

\footnotetext{
1 Rozmaryn (1961): 903.

O pojęciu i naturze zasad ogólnych zob. Kordela (2012): 101; Maroń (2011): 59 n.

3 Łaszczyca (2003): 120.
} 
że wyłączenie organu i pracownika od udziału w postępowaniu administracyjnym należy do tych instytucji procesowych, które służą przede wszystkim urzeczywistnieniu zasady dochodzenia prawdy obiektywnej (art. 7 k.p.a.) i pogłębiania zaufania obywateli do organów administracji ${ }^{4}$. Podkreślano także, że bezstronne i uczciwe działanie urzędnika jest także wymogiem Europejskiego kodeksu dobrej administracji (art. 8 i 11).

III. Ujęcie bezstronności w ramy zasady prawnej ma określone znaczenie. Z uwagi na interpretacyjną funkcję zasad ogólnych ewentualne wątpliwości dotyczące rozumienia szczegółowych przepisów zapewniających realizację tej zasady powinny być rozstrzygane w ten sposób, by osiagnąć wartość w postaci bezstronności. Nie oznacza to obowiązku szerokiego ich rozumienia, zwłaszcza przesłanek określonych wyłączeń podmiotowych. Podlegają one zastosowaniu adekwatnemu, a tylko w przypadku niejasności aktualny staje się nakaz takiego interpretowania teksu prawnego, by dekodowane normy były znaczeniowo zgodne z brzmieniem zasady, albo zakaz takiej wykładni, której efektem stałaby się norma o treści niezgodnej z treścią zasady ${ }^{5}$. Stosowanie konstrukcji wyłączenia nie może zatem następować „na wypadek” czy w celu uniknięcia w przyszłości jakichkolwiek zarzutów co do stronniczości. Trafne jest stwierdzenie, że nie ma uzasadnionych racji automatyzm w stosowaniu przepisów o wyłączeniu ${ }^{6}$. Wyłączenie następuje w przypadkach wynikających z przepisów prawa i nie może mieć miejsca w sytuacji, gdy w określonym stanie faktycznym nie zachodzi ustawowa przesłanka wyłączenia. Z jednej strony instytucja wyłączenia jest realizacją obowiązku zapewnienia bezstronności postępowania, w sposób prosty wpływa na osiagnięcie celu zasady prawdy obiektywnej (art. 7 k.p.a.) ${ }^{7}$, lecz z drugiej strony - nie może prowadzić do ingerencji w ekonomikę procesowa, a tym samym uniemożliwiać lub utrudniać osiagnięcie innej wartości procesowej w postaci szybkości postępowania administracyjnego.

IV. Poza przepisem art. $8 \S 1$ k.p.a. pojęcia bezstronności używają normy art. $24 \S 3$ k.p.a. oraz art. $96 \mathrm{~g} \S 1$ i 2 k.p.a. Pierwsza z nich określa przesłankę wyłączenia pracownika organu od udziału w postępowaniu przez jego bezpośredniego przełożonego, natomiast druga regulacja kształtuje treść zasady bezstronności postępowania mediacyjnego. Nie sa to jednak jedyne unormowania k.p.a. dotyczące wymogu bezstronności. Zasadniczą funkcję spełniaja bowiem przepisy rozdziału 5 działu I k.p.a., czyli przepisy o wyłączeniu pracownika od udziału w postępowaniu (art. 24, art. $26 \S 1$ i $§ 3$ k.p.a.) oraz wyłączeniu organu od załatwienia sprawy (art. 25, art. $26 \S 2$ k.p.a.). Mimo braku tytułowego podkreślenia, rozdział ten obejmuje także regulację wyłączenia członka organu kolegialnego od udziału w postępowaniu (art. 27 k.p.a.). Wyłą-

\footnotetext{
${ }^{4}$ Wyrok NSA z 29 maja 1990 r., SA/Po 1555/89, ONSA 1990, nr 2/3, poz. 44.

5 Kordela (2012): 19 i cytowana tam literatura.

${ }^{6}$ Wyrok NSA z 24 maja 2018 r., I OSK 2700/17, Lex nr 2517432.

7 Wyrok WSA w Poznaniu z 17 maja 2018 r., II SA/Po 1035/17, Lex nr 2506391.
} 
czeniu - na zasadach i w trybie określonym w art. 24 k.p.a. - podlega również biegły (art. $84 \S 2$ k.p.a.).

Przedmiotem dalszych uwag będzie jedno ze wskazanych unormowań, tj. wyłączenie członka organu kolegialnego. Wybór tego zagadnienia związany jest z pytaniem, czy już sama natura organu kolegialnego nie gwarantuje realizacji wymogu bezstronności. Większa liczba osób tworzących organ determinuje bowiem nie tylko wspólne wypracowanie/ wyważenie rozstrzygnięcia, ale i większą sferę wolności od indywidualnych interesów czy uprzedzeń osoby/ osób wchodzących w skład takiego organu. Już w tym miejscu przyjąć trzeba, że regulacja tej materii jest jednak konieczna, a kolegialność nie zwalnia z wymogu bezstronności.

V. Regulacja wyłączenia członka organu kolegialnego oparta jest normach bezwzględnie obowiązujących. Nie ma wśród nich norm gwarancyjnych, umożliwiajacych stronie postępowania rezygnację z wymogu bezstronności (zgodę na wyłączenie stosowania tej regulacji w całości lub części). Jeśli mowa o tych przepisach jako gwarancyjnych ${ }^{8}$, to w znaczeniu norm gwarantujacych realizację zasady bezstronności. Są to jednocześnie normy o charakterze złożonym. Niektóre elementy instytucji wyłączenia członka organu kolegialnego określone są wprost w normach art. 27 k.p.a. Inne wynikają z odesłań prostych bądź z odpowiedniego stosowania określonych przepisów o wyłączeniu pracownika lub organu. Pozostałe podlegają zrekonstruowaniu na podstawie innych przepisów k.p.a., np. w zakresie formy wyłączenia czy też zaskarżalności. Nie wszystkie normy art. 27 odnoszą się do członka każdego organu kolegialnego. Wskazany przepis zawiera osobne elementy regulacji dotyczace tylko członków samorządowego kolegium odwoławczego. Pierwszą z nich wyznacza przepis art. $27 \S 1$ a k.p.a., określający obowiąek wyłączenia członka kolegium od udziału w postępowaniu w sprawie wniosku o ponowne rozpatrzenie sprawy, jeśli brał udział w wydaniu decyzji objętej wnioskiem, a druga - przepis art. 27 $\S 3$ k.p.a., wskazujący skutki niezdolności kolegium do załatwienia sprawy wskutek wyłączenia jego członków.

VI. Konstrukcja wyłączenia członka organu kolegialnego oparta jest na kilku elementach: a) podmiocie wyłączenia (członek organu kolegialnego), b) przesłankach (przyczynach) wyłączenia, c) formie (mechanizmie czy trybie) wyłączenia (formuła „podlega wyłączeniu” oraz „postanawia przewodniczący”), d) podmiocie wyłączającym (przewodniczący organu kolegialnego lub organu wyższego stopnia), e) inicjatywie wyłączenia (na wniosek strony, członka organu kolegialnego albo z urzędu), f) zaskarżalności czynności wyłączenia. Osobnego potraktowania wymagaja problemy skutków wyłączenia członka/ członków oraz wyłączenia tylu członków organu kolegialnego, które prowadzi do niezdolności organu kolegialnego do podjęcia uchwały z braku wymaganego quorum. Ostatnim zagadnieniem regulacji wyłączenia członka organu kolegialnego jest określenie skutków naruszenia przepisów o obowiązku takiego

\footnotetext{
${ }^{8}$ Wyrok WSA w Gliwicach z 25 kwietnia 2017 r., IV SA/Gl 117/17, Lex nr 2293424.
} 
wyłączenia. Wyodrębnione elementy konstrukcyjne oraz pozostałe problemy omówione zostaną w kolejnych fragmentach.

VII. Z przepisu art. $27 \S 1$ in principio k.p.a. wprost wynika, że wyłączeniu podlega „członek organu kolegialnego”. Wyraźnie zatem należy podkreślić, że przepis nie obejmuje swoim zakresem pracownika urzędu (biura, starostwa i innych) obsługującego organ kolegialny. Z uwagi na zakres obowiązywania k.p.a. w formule „organ kolegialny” mieści się zorganizowany i działajacy na zasadzie kolegialności organ administracji publicznej w rozumieniu art. $5 \S 2$ pkt 3 k.p.a. Pojęcie to obejmuje zarówno kolegialny organ w rozumieniu ustrojowym (np. zarząd województwa, samorządowe kolegium odwoławcze), jak i funkcjonalnym (np. Komisja Nadzoru Finansowego, Zarząd Bankowego Funduszu Gwarancyjnego, Rada Polskiej Agencji Nadzoru Audytowego, Prezydium Krajowej Rady Radców Prawnych, rada okręgowej izby radców prawnych, rada okręgowej izby architektów). Przepis dotyczy zarówno organów kolegialnych stałych, jak i organów ad hoc (np. komisja egzaminacyjna II stopnia przy Ministrze Sprawiedliwości ds. egzaminu radcowskiego). Odnosi się także do funkcjonujących fakultatywnych organów kolegialnych (np. komisji prowadzącej postępowanie w sprawie przyjęcia na studia). Nie ma także znaczenia, czy mowa jest o organie kolegialnym, którego strukturę w pełni regulują przepisy powszechnie obowiązujące, czy też o organie kolegialnym przewidzianym takim przepisami, a którego budowę (organizację) kształtują już akty prawa wewnętrznego (np. komisja stypendialna i odwoławcza komisja stypendialna - tryb ich powoływania oraz skład określa regulamin świadczeń dla studentów). Zgodnie z normami regulującymi status kolegialnych organów administracji publicznej ustaleniu podlega pojęcie „członek” takiego organu. Normy prawa ustrojowego z reguły wprost używają takiego określenia, zwykle wskazując także tryb powoływania/ wyboru oraz określony skład (ewentualnie granice co do liczby członków) albo ustalają zasady kształtowania liczby członków. W określonych przypadkach, zwłaszcza dotyczących organów kolegialnych samorządów zawodowych, obok „członka” może również występować sekretarz i skarbnik, także wchodzacy w skład organu kolegialnego. Z uwagi na różnorodność kolegialnych organów administracyjnych, w szczególności tych w ujęciu funkcjonalnym, osoba tworząca skład takiego organu nie musi być wprost nazwana członkiem. Przepisy aktów prawa wewnętrznego mogą używać innych określeń (np. pracownik, radca, student) albo opisywać wykonywaną funkcję (np. koordynator). W rezultacie przyjąć trzeba, że termin „członek” organu kolegialnego w rozumieniu art. 27 $\S 1$ k.p.a. obejmuje - co do zasady - wszystkie osoby wchodzace w skład organu kolegialnego uprawnione do podjęcia decyzji.

Sformułowana zasada nasuwa pytanie, czy „członkiem” organu kolegialnego, w aspekcie przepisów o wyłączeniu, jest również przewodniczący takiego organu i jego zastępca/ zastępcy. Odpowiedź nie jest w tym zakresie jednorodna. Z uwagi na formułę art. $27 \S 1$ k.p.a. wskazująca, że w przypadkach określonych w art. $24 \S 3$ o wyłączeniu członka organu kolegialnego postanawia przewodniczacy organu kolegialnego, przyjąc trzeba, że przewodniczacy takiego organu nie jest w tym znaczeniu jego członkiem. Przyjęcie odmiennej zasa- 
dy musiałoby oznaczać, że jest właściwy do wydania postanowienia w kwestii wyłączenia samego siebie. Mechanizm taki byłby niewątpliwie nie do pogodzenia z treścią art. 8 k.p.a. Należy jednak zastrzec, że przepisy szczególne mogą taką zasadę modyfikować, ale wówczas konieczna jest w nich odrębna regulacja dotycząca wyłączenia przewodniczącego. Wynikająca z przepisu dwupodmiotowa relacja „członek organu kolegialnego” i „przewodniczacy organu kolegialnego" oznacza, że w przypadku, gdy przepisy prawa ustrojowego wyodrębniają stanowisko zastępcy przewodniczącego organu kolegialnego, to w zakresie wyłączenia jest on traktowany, o ile przepisy szczególne nie stanowią inaczej, jako członek organu kolegialnego. Podlega tym samym wyłączeniu przez przewodniczącego organu kolegialnego.

VIII. Przesłanki wyłączenia członka organu kolegialnego określone zostały przez odesłanie do przyczyn wyłączenia pracownika. Formuła art. $27 \S 1$ : „członek organu kolegialnego podlega wyłączeniu w przypadkach określonych w art. $24 \S 1$ ” i dalsza jej część „o wyłączeniu tego członka w przypadkach określonych w art. $24 \S 3$ postanawia [...]" wskazuje na obowiązek prostego stosowania przepisów odniesienia, czyli norm art. $24 \S 1$ i 3, a także, mimo braku wyraźnego odesłania, również przepisu art. 24 § 2 k.p.a. ${ }^{9}$ Regulacja ta pozwala wyodrębnić zatem dwie grupy przesłanek wyłączenia członka organu kolegialnego. Pierwszą tworzą przyczyny wymienione w art. $24 \S 1$ k.p.a., czyli przyczyny wyraźnie określone, „nazwane”. Są jednocześnie przyczynami skonkretyzowanymi, a tylko wyjatkowo opisanymi formułami ocennymi (mowa o przesłance określonej w pkt 1 in fine k.p.a.). Zasadniczo nadają się do stosowania w bezpośrednim rozumieniu ${ }^{10}$. Oparte sa na regulacji pełnej, a nie tylko przykładowej. Druga grupa przyczyn ma natomiast wymiar ocenny i mieści się w formule „okoliczności niewymienionych w $\S 1$, które mogą wywołać wątpliwość co do bezstronności pracownika”, jeżeli ich istnienie zostanie uprawdopodobnione. Sa to zatem przyczyny „nienazwane”, nieskonkretyzowane, tym samym o wymiarze otwartym, a jedynie opisane przez potencjalny skutek w postaci formuły „mogą wywoływać wątpliwości co do bezstronności pracownika”). Wzajemny stosunek tych dwóch grup można określić jako relację unormowania podstawowego i dopełniającego. Charakterystyczny jest dla nich mechanizm ich stosowania. Przyczyny „nazwane” tworza swoisty mechanizm „wyłączenia” stwierdzającego (deklaratoryjnego), „nienazwane” zaś wymagają „wyłączenia” kształtującego (konstytutywnego).

IX. Wszystkie przesłanki wyłączenia członka organu kolegialnego, zarówno nazwane, jak i nienazwane, maja charakter obligatoryjny. W przypadku ich zaistnienia wyłączenie jest konieczne. Nie ma wśród nich przesłanek fakultatywnych ${ }^{11}$, pozostawiających organowi uznanie co do wyłączenia lub od-

9 Adamiak, Borkowski (2019): 233-234.

${ }^{10}$ Uchwała NSA 7 sędziów z 22 lutego 2007 r., II GPS 2/06, ONSAiWSA 2007, nr 3, poz. 61.

11 Na wyłączenie fakultatywne, oparte na regulacji art. 24 § 3 k.p.a., obok wyłączenia obligatoryjnego, wskazuje Żukowski (Żukowski, Sawuła 2012: 56-57). Podkreśla, że przepis ten rozszerza przesłanki wyłączenia i pozwala na elastyczne traktowanie tej instytucji. 
mowy wyłączenia. Wątpliwości w tym zakresie nasuwa pogląd Andrzeja Wróbla, dopuszczajacy sferę uznania w wyłączeniu członka organu kolegialnego w przypadkach określonych w art. $24 \S 3$ k.p.a. ${ }^{12}$

X. Co do zasady, z zastrzeżeniem przepisów szczególnych, do członka organu kolegialnego znajdują zastosowanie wszystkie „nazwane” przyczyny wyłączenia. Wynika to wprost z przyjętego odesłania do „przypadków określonych w art. $24 \S 1$ ”. Nauka sygnalizuje jednak trudności lub niemożność stosowania wszystkich przyczyn, upatrujacc ich w formule „pracownik” użytej w art. 24 k.p.a. ${ }^{13}$ Wątpliwości powstają jedynie w odniesieniu do przyczyny wskazanej w art. $24 \S 1$ pkt 7 k.p.a. W związku ze składem organu kolegialnego (członkowie, zwykle bez rozróżnienia), trudno przyjąć istnienie stosunku nadrzędności służbowej w jego obrębie. Taka relacja mogłaby być jedynie aktualna w ujęciu: przewodniczący organu kolegialnego a członek organu kolegialnego. Nie można jednak wykluczyć, że członek organu kolegialnego będzie jednocześnie wykonywał inne zadania/ inną funkcję w innym organie lub podmiocie, a stosunek nadrzędności służbowej wystapi w układzie zewnętrznym, wykraczającym poza skład organu kolegialnego. Przepis art. $24 \S 1$ pkt 7 k.p.a. nie zawęża „stosunku nadrzędności służbowej” do tego organu, który prowadzi postępowanie. Pozostałe określone przyczyny wyłączenia można ująć w dwóch zasadniczych grupach, wydzielonych z uwagi na postać bliskości członka organu kolegialnego ze sprawa administracyjną (przyczyny przedmiotowe wymienione w art. $24 \S 1$ : pkt 1 in principio, pkt 4 in principio, pkt 5 i 6) lub ze strona postępowania (przyczyny podmiotowe wymienione w art. $24 \S 1$ : pkt 1 in fine, pkt 2, 3, pkt 4 in fine).

XI. Przyczyny nienazwane wyłączenia członka organu kolegialnego zawsze wymagają indywidualnej oceny. Nie wystarczy ogólnikowy zarzut, że postępowanie nie jest prowadzone obiektywnie ${ }^{14}$. Ocena taka konieczna jest już ze względu na brzmienie art. 24 § 3 k.p.a., które wymaga badania w dwóch zakresach: uprawdopodobnienia istnienia okoliczności niewymienionych w art. $24 \S 1$ oraz ich charakteru jako mogacych wywołać wątpliwość co do bezstronności członka organu kolegialnego. Należy zauważyć, że przepis wymaga jedynie uprawdopodobnienia istnienia okoliczności, nie zaś ich udowodnienia. Zasadnicza sfera oceny odnosi się do formuły „istnienia okoliczności [...], które mogą wywołać wątpliwość co do bezstronności pracownika”. Jej istota jest eliminacja nawet potencjalnych wątpliwości co do braku bezstronności członka organu kolegialnego. Mowa bowiem o okolicznościach, które „moga” wywoływać, a nie takich, które „wywołują lub „wywołaja” wątpliwości. Dla samej zaś „wątpliwości” wystarczy niepewność, wahanie, powątpiewanie $^{15}$. W konsekwencji dla wyłączenia członka organu kolegialnego

12 Wróbel (2018): 259.

${ }^{13}$ Chróścielewski (2019): 216.

${ }^{14}$ Wyrok NSA z 11 stycznia 2011 r., I OSK 347/10, Lex nr 786821.

15 Doroszewski (1969); wyrok WSA w Kielcach z 20 lutego 2018 r., II SA/Ke 157/17, Lex nr 2465731; wyrok WSA w Gdańsku z 12 lutego 2015 r., III SA/Gd 859/14, Lex nr 1649969. 
zgodnie z omawiana podstawa prawną wymagane jest wyłącznie uprawdopodobnienie, że mogą istnieć wątpliwości co do jego bezstronności, a nie, że jest on rzeczywiście stronniczy ${ }^{16}$. W ogólności wskazuje się na okoliczności faktyczne lub prawne, na pojedyncze fakty lub zdarzenia czy sytuacje istniejące dłużej, powodujące wątpliwości co do bezstronności, które mogą dotyczyć życia prywatnego, pracy zawodowej, zajęcia ubocznego, działalności politycznej lub społecznej, wyrażanych lub demonstrowanych publicznie poglądów i przekonań. Właściwie może być podniesiona każda okoliczność mająca związek ze stosunkiem pracownika do sprawy, w której prowadzone jest z jego udziałem postępowanie administracyjne ${ }^{17}$.

Na podstawie przykładów wskazywanych w nauce i judykaturze, nie zawsze zgodnych, odnotować można w szczególności przyczyny związane z relacjami o nasileniu podmiotowym, zwłaszcza w postaci: łączących członka organu kolegialnego ze stroną postępowania (nie zaś z innymi podmiotami ${ }^{18}$ ) stosunków towarzyskich ${ }^{19}$, nieraz dookreślanych jako bliskich ${ }^{20}$, występowanie w charakterze strony szkolnego ${ }^{21}$ lub uczelnianego kolegi/ koleżanki członka organu kolegialnego, pozostawania członka organu kolegialnego i strony postępowania w relacjach sąsiedzkich ${ }^{22}$, niezależnie, czy są to stosunki sporne czy niesporne, pozostawanie przez członka organu ze strona w stosunku konkubinatu, w stosunku pokrewieństwa z osobą wchodzaca w skład organu strony niebędącej osobą fizyczna, w stosunku emocjonalnym, wywołującym pozytywne lub negatywne nastawienie do strony postępowania ${ }^{23}$, którego źródłem może być poważny konflikt osobisty, prawny lub moralny ${ }^{24}$. Mogą być to również relacje o podłożu przedmiotowym, także związane ze sprawą administracyjna, m.in. przypadek złożenia przez stronę skargi na członka organu co do niewłaściwego jego zachowania się $e^{25}$ albo przypadek, gdy pracownik był biegłym lub świadkiem w postępowaniu cywilnym, karnym lub innym, a przedmiot tego postępowania był powiązany ze sprawa administracyjną ${ }^{26}$.

Ocena konkretnych okoliczności może być również negatywna i tym samym prowadzić do odmowy wyłączenia członka organu kolegialnego, m.in.: okoliczność naruszania prawa przez członka organu kolegialnego czy też przez sam organ kolegialny ${ }^{27}$, okoliczność dotycząca wszczęcia postępowania karne-

\footnotetext{
16 Wyrok NSA z 17 sierpnia 2018 r., I GSK 144/2018, Lex nr 2551655.

17 Adamiak, Borkowski (2019): 213; Majchrzak (2002): 166; Zalasińska (2011): 150.

18 Wyrok WSA we Wrocławiu z 2 lipca 2013 r., III SA/Wr 214/13, Lex nr 1355799.

19 Wyrok WSA we Wrocławiu z 29 stycznia 2015 r., II SA/Wr 858/14, Lex nr 1654592.

20 Janowicz (1996): 103.

21 Starościak (1970): 82.

22 Martysz (2010): 251.

23 Wrzesińska-Nowacka (2012): 98.

${ }^{24}$ Starościak (1970): 82.

25 Janowicz (1996): 103.

26 Wyrok NSA z 7 grudnia 2011 r., II GSK 1270/10, Lex nr 1151606; wyrok WSA w Krakowie z 29 grudnia 2010 r., II SA/Kr 1113/10, Lex nr 753421.

27 Wrzesińska-Nowacka (2012): 98.
} 
go wobec członka organu o niedopełnienie obowiązków służbowych ${ }^{28}$, okoliczność wykonywania innych czynności zawodowych (np. prowadzenie kancelarii prawnych) pod tym samym adresem przez członka organu kolegialnego i stronę postępowania ${ }^{29}$ czy też uczestnictwo członka organu kolegialnego wspólnie z innymi osobami, w tym ze stroną postępowania, w organizowaniu określonych dużych, często publicznych przedsięwzięć, wydarzeń, imprez. Samo wykonywanie przez członka organu kolegialnego innych zadań/ funkcji publicznych w innym organie administracji publicznej (innej instytucji), niezależnie od ich podstawy prawnej, nie jest przyczyną wyłączenia tego członka w przypadku, gdy strona postępowania jest osoba, w stosunku do której członek organu kolegialnego uczestniczył w wydaniu rozstrzygnięcia przez inny organ. Również przynależność do tej samej grupy zawodowej (wykonywanie tego samego zawodu), uczestniczenie przez członka organu kolegialnego ze strona postępowania w określonym prawem zespole (np. gremium naukowym), komisji (np. egzaminacyjnej), o ile jest zasiadaniem na równych prawach, nie musi oznaczać konieczności wyłączenia członka. Jeśli prowadziłoby to jednak do powstania określonej więzi, np. skierowanej na wspólną działalność badawcza czy publikacyjna, wystapiłaby przyczyna wyłączenia.

XII. Problem formy wyłączenia członka organu kolegialnego należy do złożonych. Wątpliwości związane są z dwoma formułami: „podlega wyłączeniu” (art. $27 \S 1$ zd. 1, art. $27 \S 1$ a k.p.a.) oraz „postanawia przewodniczący” (art. 27 $\S 1$ zd. 2 k.p.a.). O ile ta ostatnia, dotycząca nienazwanych przyczyn wyłączenia członka organu kolegialnego wskazuje na formę postanowienia administracyjnego, o tyle pierwsza z nich, odnosząca się do przyczyn nazwanych, nie jest jednoznaczna. Formuła „członek organu kolegialnego podlega wyłączeniu” może być rozumiana zarówno jako podstawa wyłączenia z mocy prawa, jak i podstawa do wydania postanowienia o wyłączeniu członka. Przeważa pogląd o wyłączeniu członka organu kolegialnego z mocy prawa ${ }^{30}$. Prezentowane jest jednak także stanowisko o konieczności wydania w tej sprawie rozstrzygnięcia $^{31}$. Za potrzebą wydania postanowienia administracyjnego w kwestii wyłączenia członka organu kolegialnego mogą przemawiać następujące argumenty $^{32}$. Po pierwsze, wyłączenie członka jest wynikła w toku postępowania, nie zaś wewnątrzorganizacyjna, kwestia procesową w rozumieniu art. $123 \S 2$ k.p.a. Rozstrzygnięciu w szczególności wymagać mogą wątpliwości związane z ocenna przyczyną wyłączenia członka (art. $24 \S 1$ pkt 1 in fine k.p.a.). Nie można także wykluczyć ewentualnego żądania strony wyłączenia członka, opartego na przyczynach wymienionych w art. $24 \S 1$. Judykatura jednoznacznie podkreśla, że „zgłoszenie wniosku o wyłączenie, nawet przy braku podstaw do jego uwzględnienia, rodzi obowiązek po stronie właściwych organów admi-

28 Zob. wyrok NSA z 3 lutego 2017 r., II OSK 1683/15, Lex nr 2261538.

29 Wyrok WSA we Wrocławiu z 29 stycznia 2015 r., II SA/Wr 858/14, Lex nr 1654592.

${ }^{30}$ Dawidowicz (1983): 69; Adamiak, Borkowski (2019): 235 z odesłaniem do 202; Kędziora (2017): 205; Knysiak-Molczyk (2013): 145.

31 Żukowski (2012): 59 z odesłaniem do 57.

32 Łaszczyca (2011): 142-143. 
nistracji do jego rozpoznania"33. Po wtóre, prowadzi to do jednolitego procesowego - w znaczeniu formy - stosowania instytucji wyłaczenia członka, bez względu na przyczynę wyłączenia (art. 24 § 1 i 3) ${ }^{34}$. Można także, w kategoriach posiłkowych, podnieść kwestię techniki regulacji tej materii. Przepis art. 27 $\S 1$ posługuje się formuła „członek [...] podlega wyłączeniu”, bez dookreślenia podstawy wyłączenia, a zatem inaczej niż czynią to regulacje niektórych procedur sądowych, w których wyraźnie oznaczono ustawę jako źródło wyłączenia (np. art. 18 § 1 P.p.s.a. - „z mocy samej ustawy”). Dla usunięcia wskazanych rozbieżności można zaproponować także następujący sposób: przyjać dla przyczyn nazwanych mechanizm wyłączenia z mocy prawa, ale pozostawić formę postanowienia dla przypadków wątpliwych, zwłaszcza w sytuacji różnej oceny określonych okoliczności przez członka organu kolegialnego i przewodniczącego tego organu. Temu ostatniemu należy zagwarantować prawną możliwość władczej ingerencji (w formie postanowienia) ukierunkowanej na zapewnienie bezstronności postępowania.

Treść postanowienia w kwestii wyłączenia nie może nasuwać jakichkolwiek wątpliwości co do wskazania członka organu kolegialnego, którego wyłączenie obejmuje $\mathrm{e}^{35}$. Jednoznacznego sprecyzowania w postanowieniu wymaga także postępowanie (przez wskazanie sprawy administracyjnej), w którym to wyłączenie następuje. Nie obejmuje ono bowiem udziału w postępowaniach dotyczących innych spraw, choćby to były sprawy tego samego rodzaju ${ }^{36}$.

Postanowienia wydawane na podstawie przepisu art. $27 \S 1$ i $\S 1$ a k.p.a. mogą rozstrzygać „o wyłączeniu” członka, jak i „o odmowie wyłączenia członka”. Ich charakter prawny jest w niektórych płaszczyznach odmienny. Postanowienie wydawane w związku z przyczynami nazwanymi jest aktem deklaratoryjnym (skutki wyłaczenia członka powstaja z momentem wystapienia przyczyny wyłączenia - postanowienie o wyłączeniu działa tu zatem ex tunc), natomiast podejmowane w odniesieniu do przyczyn nienazwanych - aktem konstytutywnym (twórczym, wiążącym skutki prawne z momentem jego doręczenia lub ogłoszenia, czyli ex nunc). Oba rodzaje postanowień są natomiast aktami zwiąanymi: „członek [...] podlega wyłączeniu”, przewodniczący „postanawia”).

XIII. Podmiotem wyłączającym członka organu kolegialnego jest „przewodniczący organu kolegialnego lub organu wyższego stopnia”. Wskazana w przepisie kolejność ma znaczenie prawne. Przewodniczący organu kolegialnego, w skład którego wchodzi członek podlegający wyłączeniu, jest podstawowym podmiotem wyposażonym w zdolność do wydania postanowienia w tej kwestii. Zdolność przewodniczącego organu wyższego stopnia ma w tej formule charakter ograniczony. Podkreślić trzeba, że chodzi tu o odrębną zdolność „przewodniczącego organu wyższego stopnia”, a nie „organu wyższego stopnia”, co

${ }^{33}$ Wyrok NSA z 21 grudnia 2007 r., I OSK 383/07, Lex nr 372671; wyrok WSA w Gliwicach z 29 października 2009 r., II SA/Gl 458/09, Lex nr 573708.

${ }^{34}$ Janku (1970): 121.

35 Zob. wyrok NSA z 13 grudnia 2007 r., I OSK 307/07, Lex nr 470178; wyrok NSA z 3 grudnia 2007 r., I OSK 261/07, Lex nr 470144.

36 Dawidowicz (1962): 93. 
w rezultacie oznacza, że pojęcie przewodniczącego organu wyższego stopnia w rozumieniu art. $27 \S 1$ zd. 2 k.p.a. obejmuje wyłącznie „przewodniczącego organu kolegialnego wyższego stopnia”. Nauka prawa procesowego nie jest zgodna co do przesłanek zdolności „przewodniczącego organu kolegialnego wyższego stopnia” do wydania postanowienia w kwestii wyłączenia członka organu kolegialnego. Zdaniem Janusza Borkowskiego „chodzić będzie o przypadki wyłączenia całego składu organu kolegialnego, gdy zsumują się przypadki wyłączenia poszczególnych jego członków" ${ }^{37}$. Natomiast w ocenie Wróbla przepis obejmuje przypadki, kiedy wyłączeniu podlega przewodniczący organu kolegialnego $^{38}$. Za ostatnim poglądem przemawiają względy natury systemowej. Przepis art. $27 \S 1$ zd. 2 k.p.a. odnosi się wprost do członka organu kolegialnego, a nie do samego organu kolegialnego. W ujęciu procesowym, w odniesieniu do mechanizmu działania organu kolegialnego, członkiem organu kolegialnego jest (dla organów kolegialnych orzekajacych w całym składzie) lub może być (w odniesieniu do przypadku, gdy czynności orzecznicze wykonują oznaczone zespoły) także przewodniczący tego organu kolegialnego. W sytuacji zatem, gdy wyłączeniu podlega ten ostatni (jako „członek orzekający”), a jednocześnie organem wyższego stopnia jest organ kolegialny, rozstrzygnięcie w kwestii wyłączenia przewodniczącego organu kolegialnego podejmuje przewodniczący organu kolegialnego wyższego stopnia. Z orzekania w tej materii wyłaczony jest natomiast organ kolegialny. Rozwiązanie to, a należy je ocenić jako trafne, podyktowane jest wymogiem sprawności działania w sferze procesowej. W przypadku natomiast, gdy organem wyższego stopnia w stosunku do organu kolegialnego jest organ monokratyczny, przyjać trzeba, że to on staje się zdolny do wydania postanowienia w kwestii wyłączenia przewodniczącego organu kolegialnego niższego stopnia ${ }^{39}$.

Przepisy szczególne mogą modyfikować powyższe zasady. Takie rozwiązanie wprowadza m.in. przepis art. 11 ust. 8 ustawy o nadzorze nad rynkiem finansowym. O wyłączeniu Przewodniczącego Komisji Nadzoru Finansowego od udziału w postępowaniu w sprawie w przypadkach określonych w art. 24 $\S 3$ k.p.a. postanawia sama Komisja, podejmujac uchwałę bez udziału Przewodniczącego Komisji na wniosek strony, Przewodniczącego Komisji, Zastępcy Przewodniczącego lub członka Komisji.

Kodeks nie reguluje w sposób bezpośredni i ogólny przypadku wyłączenia przewodniczącego organu kolegialnego, dla którego przepisy nie ustanawiaja już organu wyższego stopnia. Pewien tylko kierunek może wynikać z normy art. $27 \S 3$ k.p.a. W stosunku do samorządowego kolegium odwoławczego, które samo jest organem wyższego stopnia, przyjęto rozwiązanie wyjątkowe (minister właściwy do spraw administracji publicznej wyznacza inne kolegium). Przyjąć trzeba, że również w stosunku do innych organów kolegialnych zajmujących w strukturze procesowej pozycję ostatnią rolą ustawodawcy będzie wskazanie określonego szczególnego podmiotu wyłączającego.

\footnotetext{
37 Adamiak, Borkowski (2019): 235.

38 Wróbel (2018): 260. Pogląd ten aprobuje Klonowski (2015): 175.

39 Łaszczyca (2011): 113; Martysz (2010): 274.
} 
XIV. Inicjatywa wyłączenia członka organu kolegialnego została ukształtowana szeroko. W przypadku akceptacji poglądu, jak wyżej wskazano niejednoznacznego, o wynikajacym z przepisu art. $27 \S 1 \mathrm{zd}$. $1 \mathrm{i} \S 1 \mathrm{a} \mathrm{k.p.a.} \mathrm{mechani-}$ zmie wyłączenia członka z mocy prawa, jego „odsunięcia” dokonuje wówczas norma prawna, a rolą członka powinno być $\mathrm{w}$ istocie jedynie złożenie oświadczenia o wystapieniu takiego skutku z uwagi na oznaczoną przyczynę nazwaną wyłączenia. Tylko co do zasady omawiany mechanizm eliminuje problem inicjatywy wyłączenia, „zamykając” ją w działaniu samego przepisu prawa. Nie jest bowiem wykluczone, że także w odniesieniu do nazwanej przyczyny wyłączenia członka o jego wyłączenie wystapi strona postępowania. Niezbędne stanie się wówczas rozstrzygnięcie tej kwestii w formie postanowienia przewodniczącego organu kolegialnego. Inicjatywa może także pochodzić od samego przewodniczącego organu kolegialnego w sytuacji sporu między członkiem a przewodniczącym co do wystapienia przesłanki wyłączenia, zwłaszcza przesłanki ocennej pozostawania z jedną ze stron w takim stosunku prawnym, że wynik sprawy może mieć wpływ na jego prawa lub obowiązki (art. $24 \S 1$ pkt 1 in fine k.p.a.).

W przypadku wystapienia przesłanki nienazwanej postanowienie o wyłaczeniu członka może być wydane na wniosek strony, członka organu kolegialnego albo z urzędu. Wniosek, o którym mowa, stanowi formę podania w rozumieniu art. $63 \S 1$ k.p.a. i powinien odpowiadać wymaganiom co do formy podania i jego treści. Zgłoszony wniosek wszczyna postępowanie wpadkowe (incydentalne). Jego przedmiotem jest ocena zaistnienia nienazwanej przesłanki wyłączenia członka organu kolegialnego. Kwestia ta wymaga rozstrzygnięcia, które przyjmuje formę postanowienia.

XV. Postanowienie w kwestii wyłączenia członka organu kolegialnego, niezależnie od przyczyny wyłączenia (nazwanej czy nienazwanej), jest czynnością orzecznicza, na która nie przysługuje zażalenie. Nie ma w tym zakresie znaczenia treść rozstrzygnięcia. Kodeks nie przewiduje zażalenia zarówno w przypadku wydania postanowienia „o wyłączeniu członka organu kolegialnego”, „o odmowie wyłączenia” czy też „o umorzeniu” postępowania wpadkowego w kwestii wyłączenia członka (np. w sytuacji gdy z wnioskiem o wyłączenie wystapiła osoba, która nie jest stroną postępowania - art. $27 \S 1 \mathrm{w} \mathrm{zw}$. $\mathrm{z}$ art. $126 \mathrm{i}$ w zw. z art. $105 \S 1$ k.p.a.). Brak prawa zażalenia jest konsekwencją regulacji art. $141 \S 1$ k.p.a., która nadaje zażaleniu charakter środka prawnego konkretnego $0^{40}$, czyli dopuszczalnego tylko wówczas, gdy Kodeks tak stanowi. Takiego środka zaskarżenia nie przewidują jednak normy art. 27 k.p.a. ani też regulacja art. 24 k.p.a. Ta ostatnia i tak nie znalazłaby zastosowania co do zaskarżalności z uwagi na jej stosowanie tylko co do przyczyn wyłączenia (odesłanie zawężające). Trybunał Konstytucyjny uznał, że przepis art. 24 k.p.a. w zw. z art. $141 \S 1$ k.p.a. (w zakresie, w jakim nie przewiduje zażalenia na postanowienie o odmowie wyłączenia pracownika) jest zgodny z art. 2 i art. 45 ust. 1 Konstytucji RP oraz nie jest niezgodny z art. 6 ust. 1 i art. 13

40 Łaszczyca (2000): 41. 
Konwencji o ochronie praw człowieka i podstawowych wolności ${ }^{41}$. Podkreślił, że prawo strony do wyłączenia pracownika nie jest ani bezpośrednim prawem konstytucyjnym, ani też nie wynika z przepisów obowiązującego prawa materialnego, nie przesadza ostatecznie o prawach i obowiązkach strony, a jest instytucja proceduralna, w ramach której stronie służy uprawnienie gwarantujące obiektywne rozstrzygnięcie sprawy. Ocena ta jest również adekwatna w przypadku postanowienia o odmowie wyłączenia członka organu kolegialnego. Postanowienie w tej kwestii może być zaskarżone przez stronę jedynie w odwołaniu od decyzji (art. 142 k.p.a.).

XVI. Zasadniczym skutkiem wyłączenia członka organu kolegialnego jest jego odsunięcie od udziału w postępowaniu. Ma ono wymiar bezwzględny. Nie kreuje bowiem obowiązku członka organu kolegialnego podejmowania czynności niecierpiących zwłoki ze względu na interes społeczny lub ważny interes stron. Przepis art. $27 \S 1$ k.p.a. nie odsyła, choćby odpowiednio, do normy art. $24 \S 4$ k.p.a. Brak takiego obowiązku wynika z możliwości wykonania wskazanych czynności przez innego członka organu kolegialnego. Członek organu kolegialnego podlega wyłączeniu w ogólności od udziału w postępowaniu, nie zaś od udziału w poszczególnych tylko czynnościach procesowych.

W określonych tylko przypadkach skutkiem wyłączenia członka organu kolegialnego jest powstanie obowiazku wyznaczenia innego członka tego organu do udziału w rozpoznaniu i rozstrzygnięciu sprawy. Dotyczy on tych organów kolegialnych, w których czynności orzecznicze wykonuja oznaczone zespoły czy składy członków organu kolegialnego (np. samorządowe kolegium odwoławcze orzekające w składzie trzyosobowym). W sytuacji wyłączeniu określonego członka takiego składu przewodniczacy organu kolegialnego w formie postanowienia wyznacza wówczas innego członka określonego zespołu orzekającego. Postanowienie to ma wówczas podstawę prawną w przepisie art. 123 $\S 2$ k.p.a. Wskazany skutek nie powstaje w sytuacji, gdy organ kolegialny działa in pleno. Następuje wówczas „pomniejszenie” składu organu kolegialnego i w takiej formule organ rozpoznaje i rozstrzyga sprawę.

Inne następstwa dotyczą natomiast przypadku, gdy wskutek wyłączenia większej (zwykle) liczby członków organu kolegialnego, organ ten stał się niezdolny do podjęcia uchwały z braku wymaganego quorum. Stosuje się wówczas odpowiednio przepisy art. $26 \S 2$, czyli normy określające skutki wyłaczenia organu. Jeżeli wskutek wyłączenia członków sprawy nie może załatwić samorządowe kolegium odwoławcze, to wówczas minister właściwy do spraw administracji publicznej, w drodze postanowienia, wyznacza inne samorządowe kolegium odwoławcze (art. $27 \S 3$ k.p.a.).

XVII. Naruszenie przepisów realizujących wymóg bezstronności postępowania stanowi - przy uwzględnieniu teorii gradacji wad aktu administracyjnego - wadę istotna, która już z uwagi na sferę, której dotyczy, jest wada procesowa. Kodeks nie traktuje jej jednak jako wady istotnej kwalifikowanej

${ }^{41}$ Wyrok TK z 7 marca 2005 r., P 8/03, OTK-A 2005, nr 3, poz. 20. 
(wady nieważności), lecz wiąże z nią skutek w postaci wzruszalności decyzji. Formułuje obowiązek wznowienia postępowania w przypadku, gdy decyzja wydana została przez pracownika lub organ administracji publicznej, który podlega wyłączeniu stosownie do art. 24, 25 i 27 k.p.a. (art. $145 \S 1$ pkt 3 k.p.a.).

Przytoczony przepis nasuwa wątpliwości w jego stosowaniu wobec członka organu kolegialnego. Mowa jest w nim bowiem tylko o wydaniu decyzji przez pracownika lub organ administracji publicznej, a z pominięciem członka organu kolegialnego. Dalej zaś, wskazując na podstawy wyłączenia, przepis wymienia art. 27 k.p.a. Przepis nie różnicuje także następstw braku wyłączenia w zależności od składu organu kolegialnego i sposobu jego działania. Zasygnalizowane wątpliwości wymagają rozstrzygnięcia przez przyjęcie zasady, że wskazana wada wzruszalności decyzji (przesłanka wznowienia postępowania) znajduje zastosowanie do członka organu kolegialnego. Konieczne jest jednak wydzielenie dwóch różnych zakresów. Pierwszy obejmuje dwa przypadki, tj. gdy podlegający wyłączeniu członek organu kolegialnego: a) uczestniczył w wyznaczonym ('́cisłym) składzie zespołu organu kolegialnego (np. członek trzyosobowego składu orzekającego samorządowego kolegium odwoławczego) oraz b) „zapewnił” organowi kolegialnemu wymagane quorum. Drugi zwiazany jest z sytuacja, gdy udział członka organu kolegialnego w wydaniu decyzji prowadził tylko do niewłaściwego składu organu (jego niewłaściwej obsady).

Pierwszy zakres objęty jest wskazaną podstawą wznowienia. Podlegający wyłączeniu członek określonego składu (zespołu) nie zapewnił należytego składu organu. W przypadku organu działającego in pleno udział „wyłączonego" członka zapewniającego quorum oznacza w istocie, że organ nie miał wymaganego quorum i wówczas zastosowanie znajduje fragment art. $145 \S 1$ pkt 3 k.p.a. stanowiący o „wydaniu decyzji przez organ administracji publicznej, który podlega wyłączeniu stosowanie do art. 27 k.p.a.”, a konkretnie stosownie do art. $27 \S 2$ k.p.a.

Drugi zakres nie jest wprost uregulowany w k.p.a., jednak zasadniczo zgodnie oceniany jest $\mathrm{w}$ poglądach nauki. Proponowane jest przyjęcie takiej wykładni przepisu, która pozwoliłaby na wznowienie postępowania także w przypadku, gdy decyzja została wydana przez organ kolegialny przy udziale członka, który podlega wyłączeniu ${ }^{42}$. Proponuje się, że „przy wykładni tej podstawy należy dać pierwszeństwo prawu jednostki do obrony na drodze sprawiedliwej procedury, którą może zapewnić tylko instytucja publiczna działająca w myśl reguł rzetelności [...]"43. Rzetelna zaś procedura to procedura bezstronna. Zatem także w przypadku szerszego składu organu kolegialnego, w zakresie którego udział w orzekaniu jednego z członków podlegających wyłączeniu mógłby w rzeczywistości nie przesądzić o wyniku głosowania, postępowanie zakończone taką decyzją i tak podlega wznowieniu. Przypadek taki może mieć natomiast wpływ na wynik postępowania wznowieniowego. Zgodnie bowiem z treścią art. $146 \S 2$ k.p.a. nie uchyla się decyzji dotychczasowej,

42 Dawidowicz (1962): 232; Iserzon (1970): 248; Janowicz (1996): 344.

${ }^{43}$ Adamiak (2019): 826. 
jeżeli w wyniku wznowienia postępowania mogłaby zapaść wyłącznie decyzja odpowiadająca w swej istocie decyzji dotychczasowej. Nie można wykluczyć przypadku, że wynik głosowania jest tak jednoznaczny, że wyłączenie jednego członka organu kolegialnego nie miałoby istotnego wpływu na treść podjętej decyzji.

XVIII. Przeprowadzona analiza skłania do wniosku, że mimo natury organu kolegialnego regulacja wyłączenia członka tego organu w celu realizacji wymogu bezstronności postępowania jest konieczna. Każde bowiem z ogniw, które wykonuje władzę publiczna, w tym także ,jednostkowe” w postaci członka organu kolegialnego, musi być wolne od określonych interesów czy zależności. Rolą zatem ustawodawcy jest stworzenie gwarancji osiagnięcia wskazanego wymogu w pełnym wymiarze. Regulacja kodeksowa zasadniczo standard ten realizuje. Pozytywnej oceny wymaga w szczególności przyjęta „równość” przesłanek wyłaczenia członka organu kolegialnego i pracownika organu administracji publicznej. Określone wątpliwości dotyczą niektórych elementów procedury wyłączenia członka czy też skutków naruszenia obowiązku wyłaczenia. Ich interpretacja, uwzględniająca zasadę budzenia zaufania, pozwala jednak na ich usunięcie.

Grzegorz Łaszczyca

Uniwersytet Ślaski w Katowicach

grzegorz.laszczyca@us.edu.pl

https://orcid.org/0000-0002-9846-8538

Adamiak, B., Borkowski, J. (2019). Kodeks postępowania administracyjnego. Komentarz. Warszawa.

Chróścielewski, W. (2019) [w:] Z. Kmieciak, W. Chróścielewski, W. (red.), Kodeks postępowania administracyjnego. Komentarz. Warszawa.

Dawidowicz, W. (1962). Ogólne postępowanie administracyjne. Zarys systemu. Warszawa.

Dawidowicz, W. (1983). Postępowanie administracyjne. Zarys wykładu. Warszawa.

Doroszewski, W. (red.). Słownik języka polskiego (1969, reprint 1997). Warszawa. <https://sjp. pwn.pl/doroszewski/>.

Iserzon, E. (1970) [w:] Iserzon. E., Starościak. J. Kodeks postępowania administracyjnego. Komentarz, teksty, wzory i formularze. Warszawa.

Janku, Z. (1970). Niektóre zagadnienia wyłączenia pracownika i organu według kodeksu postępowania administracyjnego. Ruch Prawniczy Ekonomiczny i Socjologiczny 32(2): 119-127.

Janowicz, Z. (1996). Kodeks postępowania administracyjnego. Komentarz. Warszawa.

Kędziora, R. (2017). Kodeks postępowania administracyjnego. Komentarz. Warszawa.

Klonowski, K. (2015) [w:] H. Knysiak-Molczyk (red.), Kodeks postępowania administracyjnego. Komentarz. Warszawa.

Knysiak-Molczyk, H. (2013) [w:] T. Woś (red.) Postępowanie administracyjne. Warszawa.

Kordela, M. (2012). Zasady prawa. Studium teoretycznoprawne. Poznań.

Łaszczyca, G. (2000). Zażalenie w ogólnym postępowaniu administracyjnym. Kraków.

Łaszczyca, G. (2011). Postanowienie administracyjne w ogólnym postępowaniu administracyjnym. Warszawa.

Łaszczyca, G., Martysz, C., Matan, A. (2003). Postępowanie administracyjne ogólne. Warszawa.

Majchrzak, B. (2002). Wyłączenie pracownika organu administracji publicznej w świetle przepisów k.p.a. Kwartalnik Prawa Publicznego 2(4): 155-179. 
Maroń, G. (2011). Zasady prawa. Pojmowanie i typologie a rola w wykładni prawa i orzecznictwie konstytucyjnym. Poznań.

Martysz, C. (2010) [w:] G. Łaszczyca, C. Martysz, A. Matan, Kodeks postępowania administracyjnego. Komentarz, Tom 1: Komentarz do art. 1-103. Warszawa.

Rozmaryn, S. (1961). O zasadach ogólnych kodeksu postępowania administracyjnego. Państwo i Prawo 16(12): 887-905.

Starościak, J. (1970) [w:] E. Iserzon, J. Starościak., Kodeks postępowania administracyjnego. Komentarz, teksty, wzory i formularze. Warszawa.

Wróbel, A. (2018) [w:] A. Wróbel, M. Jaśkowska, Kodeks postępowania administracyjnego. Komentarz. Warszawa.

Wrzesińska-Nowacka, A. (2012) [w:] L. Klat-Wertelecka, A. Mudrecki (red.), Kodeks postępowania administracyjnego. Komentarz dla praktyków. Gdańsk.

Zalasińska, K. (2011) [w:] M. Wierzbowski, A. Wiktorowska (red.), Kodeks postępowania administracyjnego. Komentarz. Warszawa.

Żukowski, L. (2012) [w:] R. Sawuła, Postępowanie administracyjne. Przemyśl-Rzeszów.

\section{THE EXCLUSION OF A MEMBER OF A COLLEGIAL BODY \\ IN GENERAL ADMINISTRATIVE PROCEDURE}

\section{S u m m a r y}

The article deals with the issue of excluding of a member of a collegial body from general administrative proceedings. This regulation aims at the implementation of the principle of impartiality of proceedings, which is based on Article $8 \S 1$ of the Code of Administrative Procedure. The author discusses the elements of the exclusion institution, in particular the notion of a member of a collegial body, the reasons for the exclusion, the form of the exclusion and the authority deciding on the exclusion, the exclusion initiative, and the effects of the exclusion. The article also sets out the effects of violating the exclusion regulation.

Keywords: administrative procedure; member of a collegial body; exclusion 
